\title{
A CASE STUDY OF SPIRITUALITY IN SENIOR CENTER EDUCATION:
}

\author{
Q U A LITATIVE RESEARCH \\ I N A D U L T D U C ATION
}

Laura Demarse, North Carolina State University

\begin{abstract}
This article presents a case study on the role of spirituality in adult education at a suburban senior center located in the southeast region of the country. The purpose of the case study was to understand the deeply personal role of spirituality in adult education as seen through teaching seniors and examine the personal manifestation of spirituality through the life experiences of three adult educators. The research questions examined how the participants implement spirituality in their teaching practice, as principally informed by their personal definitions of spirituality, and how these personal experiences of spirituality influence and shape their work as adult educators. The case study used non-participant observation and semi-structured interviews, which provide the narratives that informs the basis of this study. Three themes emerged from the data: (a) interconnectedness and contemplative practices, (b) strength and capacity building and (c) social support and community building. These themes link the personal life experience of the adult educators to unique findings which are consistent with the current scholarly discourse on spirituality in adult education; thus provide additional depth and scope to ground in practice.
\end{abstract}

Keywords: spirituality, adult education, transformation learning, case study, educators

\section{A CASE STUDY ON SPIRITUALITY IN SENIOR CENTER EDUCATION}

Spirituality in adult education provides context by which we can begin to understand and gather information on how and why certain learning experiences are personally transformative and deeply meaningful. The life experience of the adult educator and their unique lens is critical in identifying how spirituality enters the classroom and sets the tone. It is incumbent upon the educator to understand their life experience as it will inevitably inform their teaching practice and posture. Spirituality has become an important component of adult education and scholarly discourse surrounding education, social justice and transformative learning.

The following presents a descriptive case study exploring the personal experiences of three adult educators that teach at a senior center in a large suburban area in the southeast region of the United States, and it explores the personal dynamics and life experiences of the three adult educators as a conduit to gain a deeper understanding of the practice of spirituality in teaching adults. The research questions that guided the case study were:

1. How do adult educators implement spirituality in their practice?

2. How does their personal definition of spirituality influence their role as educators?

According to Tisdell (2003), spirituality is of increasing interest and focus in adult education and adult learning theory. Spirituality is an elusive 
term and open concept for many individuals. Understanding how adult educators use spirituality to inform their practice is of interest and has the potential to advance a stronger conceptual framework for using spirituality in adult education. The case provides a closer examination of the personal role spirituality plays in the life of three adult educators and how this personal definition manifests in teaching practice. The study seeks to advance this conceptual framework, as well as use spirituality as a tool to enhance teaching and learning.

The paper is organized to present the case study through the following literature review and methodology as well as offering the findings and discussion of the role of spirituality in adult education.

\section{LITERATURE REVIEW}

Spirituality and adult education has gained traction in our field and has lent insightful theory and understanding to the experience of adult learning and adult education. The term spirituality is elusive and subjective for many individuals, however, it captures the essence of a deeply held and personal process that brings people to adult education and greatly enriches personal experiences. The literature provides definitions, personal experiences, and theoretical underpinnings, all of which will be explored in the review of the literature on spirituality in adult education.

The most prolific researcher in the field of spirituality in adult education, Tisdell (2003), provides a comprehensive understanding of the definitions of spirituality and its impact on practice. Tisdell and Tolliver (2003) describe spirituality as "...a connection to what is referred to by various names as the Life Force, God, a higher power or purpose, Great Spirit, or Buddha Nature," (p. 38). Furthermore, understanding how spirituality is used to inform practice in adult learning is central to this study. Tisdell (2003) offers the following:

Whether one actually discusses spirituality directly or creates a space more implicitly depends on the content and context of the course. Since one of the fundamental aspects of spirituality is that it happens by surprise and cannot be planned, it might seem contradictory to provide a space for acknowledging the spiritual dimension.
Nevertheless, it is possible to design a curriculum and learning environment that attends to symbolic domains of learning that are part of spirituality ( $\mathrm{p}$. 212). Tisdell (2003) proffers the following definition of spirituality which is used to inform this study; "Spirituality is about awareness and honoring of wholeness and interconnectedness of all things through the mystery of Life-force, God, higher power, Buddha nature or Great Spirit-spirituality is fundamentally about meaning-making," (p.28).

\section{SPIRITED EPISTEMOLOGY}

Tisdell (2003) observes that spirituality in addition to meaning-making in adult education is also always present in the learning environment. Vella (as cited in Tisdell 2003) imparts "Every education event is a movement toward a metanoia, the passage of spirit from alienation into deeper awareness of oneself. A spirited epistemology is based on the belief that all education is directed toward such a transformation," (p. 31). Tisdell's framework further imparts the notion of authenticity as a critical aspect of developing a spirited epistemology - "A key point is that spirituality is about moving towards a greater sense of one's deepest spirit or more authentic identity,' (p. 33). Tisdell (2003) offers the adult educator the following tools to incorporate spirituality into their practice: "Engaging the learner in critical readings and engagement of new ideas (cognitive domain) understanding and weaving together how these experiences relate back to one's life experience (affective domain) and creating a space for integrating learning through the use of symbols, art of metaphor (symbolic domain)" (p. 35).

Spirituality in adult education can also be seen through examining the work of Palmer (2007) he describes teaching as combining the intellectual, emotional and spiritual, in this way: "by spiritual I mean the diverse ways we answer the heart's longing to be connected with the largeness of life-a longing that animates love and work, especially the work called teaching" (Palmer, 2007, p. 5). Palmer believes "Good teaching possesses a capacity for connectedness. Teachers are able to weave a complex web of connections among themselves, their subjects, and their students so that students learn to weave a world for themselves" (p. 11).

"Nurturing soul in adult learning" by Dirkx (1997) provides an additional lens in which to 
distill meaning from spirituality in adult learning, as he describes nurturing the soul in adult learning.

To nurture the soul is to recognize what is already inherent within our interactions, relationships and experiences, to acknowledge its presence within the teaching and learning environment, to respect the sacred message (pg. 5).

In the same way, "A spirited epistemology: Honoring the adult learner as subject," proposed the assumption that each learning event is a moment of spiritual development in which people practice being what they are. Further articulated by Vogel (2000) is the importance of respect as a guiding principle as it allows people space and is a fundamental concept for all adult educators. "Reckoning with the spiritual lives of adult educators, asserts that respect is central to the spiritually based relationship."

Lastly, in order to fully engage the lifelong, non-formal learning at the suburban senior center, understanding the developmental lifecycle of an older adult requires consideration. Erickson (1963) identified the stage for older adults $(65+)$ as ego integrity vs. despair, with the basic virtue of wisdom present. The work of this stage is to accept one's life as meaningful. This concept of finding meaning is congruent with the role of spirituality in adult education at the senior center. Erickson's theory imparts the importance of self-reflection and acceptance as developmental tasks at this stage. The role of spirituality in adult education and lifelong learning promotes both of these important life stage tasks.

\section{METHODOLOGY}

Case study research was utilized for understanding the deeply contextualized experience of spirituality in adult education at the senior center in this study. The data were collected through the interviews from the three adult educators and non-participant observation at the center. According to Yin $(1994,2011)$, the case study research provides the framework for a "rich analysis and valuable insight" into the specific program, event or phenomenon. Case studies investigate contemporary phenomenon within its real-life context, especially when boundaries between phenomenon and context are not clearly evident. In other words, "This method is utilized to cover contextual conditions -believing that they might be highly pertinent to your phenomenon of study," (p.13).

Further adhering to the principles outlined by Yin (2011) for a descriptive case study design, in order to present a detailed account of the role of spirituality in adult education. A descriptive case study is used to describe a phenomenon and the real life setting in which it occurs. (Yin, 2011) Utilizing, Yin's (2003) case study design focuses on asking "how" and "why" questions, seeks to understand behavior in its natural environment that cannot be manipulated, allows the researcher to examine contextual issues that maybe relevant to the phenomena and lastly can be used when the boundaries between the phenomenon and the context are not clear. (Baxter \& Jack, 2008).

\section{DATA COLLECTION}

The data was collected via three individual non-participant class observations, immediately followed by an in-depth interview, using a predetermined list of interview questions. Iobserved each educator's class once, total of immediately followed by a 45 to 60 -minute semi-structured interview. The interview questions provided a platform from which I engaged the participant in a topic that starts with general questions about their life and experience.

\section{DATA ANALYSIS}

The data analysis process began with my transcription of the interview recordings for both participants. Listening to my participants recordings provided an additional sensory experience, listening to their words without them present, outside the formal interview process, gave my experience and time with them more salience and texture. This is called thematic analysis, Boyatzis (1998) imparts that process is flexible as it allows the researcher the flexibility to code information and themes once uncovered and get close to the data developing a deeper appreciation for the content. After transcribing the interviews, I made notes in the margins of each transcript as various unit of information or themes clearly emerged from the participant's interviews.

Initially, I categorized situational factors (prior employment, religion, family life, interests) while also categorizing emerging theories and concepts congruent with the literature, such as spiritual congruence and capacity building. I developed 
categories based on reoccurring themes in the transcripts with linkages back to the literature to anchor and frame the category or theme. "Devising categories is largely an intuitive process, but it is also systematic and informed by the study's purpose, the investigator's orientation and knowledge, and the 'constructs made explicit by the participants in the study," (Goetz \& Lecompte, as cited by Merriam, 1988, p. 133). Through the process of categorizing data and informing the themes, it was critical to ensure opportunities for explanation building and pattern-matching from data to theory and existing research. (Yin, 1994)

Utilizing Yin's (2009) model for analyzing case study evidence, this case utilizes explanation building to attempt to "explain" the phenomenon in narrative form. Yin (2009) imparts that the explanation building process follows a number or different iterations; however, the first rule is to make an initial theoretical statement about a social behavior. Given the interest in understanding the role of spirituality in adult education and how this informs teaching practice, explanation building case study research was used as the framework for this study.

\section{CASE: SETTING AND PARTICIPANTS}

The senior center is a vibrant hub of activity and programming. Located in a large suburban area in the southeast region of the country, it is a popular retirement destination for many. The Center has a comprehensive list of courses, programs and events year-round. The classes are affordable and often free, taught by many retired subject matters experts and other qualified instructors. The Center is open six days per week and provides instructional and cultural activities year-round.

I interviewed three adult educators for this study and have used pseudonyms to protect their identities. The pseudonyms utilize the first letter of the participants' actual names. Tammie, a world religion and philosophy instructor, Cat, a tap dance instructor and Belinda, an art instructor. All three educators have been affiliated with the Center for at least several years. Interviews were conducted onsite in a conference room or classroom space at the senior center on during August of 2014. Each interview was approximately 45-60 minutes in length.

Tammie, 68, is a retired former corporate trainer and educator that developed a passion for world religion and travel. Tammie is a practicing Buddhist and teaches a course on religion and philosophy at the Center.

Belinda, 82, teaches a sketching course at the Center, she is a retired former public high school teacher from New Jersey. Belinda is an accomplished artist with a wide variety of interests ranging from photography to watercolors and football; she has been a dedicated Philadelphia Eagles fan since 1947.

Cat, 62, is a retired Town of Cary administrator and artist. Cat has a long affiliation with the Center and teaches tap and line dancing. Cat is an art lover, pet portrait artist and friend to many.

\section{FINDINGS}

From the case study data analysis that was described by Yin (2011), there were three main themes or narratives emerged from the data that structured the case: (1) the concept of interconnectedness and contemplative practices; (2) strength and capacity building as an educator; and (3) the importance of social support and community building. These three narratives provide a basis for processing this experience and framing the current discourse provided by the literature. Expressly, the themes provide insight into the role of adult educators and the personal nature of spirituality as well as its impact on teaching practice. "Once the themes are sorted, the researcher can begin to examine related features of these groups and gain insight," (Yin, 2011p. 187).

\section{INTERCONNECTEDNESS AND CONTEMPLATIVE PRACTICES}

The first research question regarding how adult educators define and implement spirituality in their practice provided several points of reference with linkages to the literature. Cat shared the following personal definition of spirituality:

\section{The spirit is what we bring to the here and now, I am only concerned with the here and now because that is what I have control over. Whatever we do "ripples forward," so it better be positive and for good purposes and not negative. While we are on this earth, do what you can about what you can.}

Cat describes the spiritual aspects of her work as: 
My students leave here euphoric. It is physically good because they can burn off energy. It's emotionally safe because it's a good environment. These people get to laugh, so that is a stress release, there are so many benefits. The primary reason people come is for socialization, the tap dance is the medium and the message is the connection. I make people feel safe and this is a safe place for expression.

Cat's response seems particularly salient and congruent with the words of Vogel (2000), "Our spiritual lives reflect the dreams, fears and commitments of our which we live, work, play and pray. When we claim our spiritual selves and take responsibility for understanding and nurturing the spiritual dimension of our being, we learn to teach with a deeper sense of which we are" (p. 18). This narrative situates the use of spirituality in context to teaching and learning.

Cat's narrative also demonstrates a strong sense of self in which MacKeracher (as cited in English 2000) imparts that "Spirituality develops from a strong sense of self, without which we would have little inclination to move out into the world," (p. 30). English (2000), states that adults learn about themselves through encounters with others. Through forming relationships, adults are provided with the opportunity to learn more about "their deepest longings and desires" in which they develop a stronger sense of self which is integral to spiritual development (p. 30).

Belinda offered the following response to how adult educators implement spirituality in their practice: "I like to feel that spirituality is about one-on-one instruction. I would like to make sure that each person gets what I think they need rather than a blanket instruction for all."

My second research question is: How does this personal definition of spirituality influence their role as an educator? Tammie provided the following response that is also congruent with contemplative practices:

Well I think of spirituality as an "Aha" moment. It's an enlightenment; it's the blooming of the heart and mind together and believing in something that is bigger than you, it does not have to be God, it can be a concept that motivates you and propels you and brings you joy. It influences my work as an educator in so many ways. I guess that is kind of an intellectual spirituality.

Tammie's reflections are congruent to the work of Orr (2000), who states that care, concern and outreach to others are integral aspects of spiritual development. "A fully integrated spiritual person reaches beyond him or herself and acknowledges the interdependence of all creation, appreciates uniqueness of others, and ultimately assumes the responsibility for caring and concern about other humans (p. 30)."

\section{STRENGTH AND CAPACITY BUILDING}

Belinda provided the following insight when I prompted her to talk about end of class and her teaching technique, where all of her students put their work up on the board for display. I asked Belinda which sketch of the bird she thought was the best, and she replied:

\section{I really don't look at things that way. I really don't try to do that. I really just try and look at the whole and see if they all seem to pick up the instruction, the point. If they get the point that I was trying to get across, then I am satisfied. You need to only worry about what you know and try and build on these strengths.}

Belinda provides insight into the non-linear process of learning to teach adults to sketch, that it is not about creating a masterpiece, rather the process of acquiring a new way of experiencing drawing. This can be further understood through the words of Dirkx (2003): "The soul responds to less structured environments and activities that bring one's inner life together with the outer world. The use of stories, images and dreams in our teaching help learners connect imaginal and intuitive dimensions through which the soul communicates (p. 6).” The mechanism for spiritual expression is painting; Belinda shepherds her students through utilizing the paints and the paint brush as a personal expression of self.

All three educators conveyed and demonstrated care and concern for others, outside of the classroom, showing spiritual dimensions as a 
person. Cat and Belinda both spoke about a strong sense of self and personal identity, which can be seen as congruent with the notion provided by Orr (2000) posits several strategies for fostering spiritual development, through which he identifies the importance of educators possessing a strong sense of self. "Human potential requires nurturing and the best way to nurture it is by building selfconfidence and sponsoring intentional activities (Orr, 2000, p.32)."

Furthermore, as seen through the lens of Vella (2000), Belinda's art class acts as a new relationship between teacher and learner, thus the teacher and learner enter into a "reciprocal relationshipdialogic teaching proposed as a transformative exchange, in which teachers and learners are involved in co-learning and co-teaching process, thereby cultivating the development of an authentic community of learners, characterized by sharing and support (p. 14)." Belinda shared with me during class that she does not view herself as in charge, rather she is constantly moving around the class to provided assistance and support.

Tammie's narrative is reminiscent of the work of Palmer (2003) and his pedagogy of the soul, "creating space that welcomes the soul". Furthermore, Hill and Johnson (2003) communicate that "addressing spirituality in our adult education practice means bringing our whole selves-mind, spirit and heart to our work and creating a learning space where learners can do the same (p. 23)." Cat and Tammie both articulated their commitment to allowing spirituality to show up when they teach and the importance of making room for it in their practice. Thus, it is through this lens that Tammie states:

\section{I kinda tapped into spirituality when I was going through a divorce. My daughter was young and just became curious, you know, and frustrated, and sort of not sure about the world and what is was all about. I be- gan to read about different religions. Bud- dhism has had a tremendous impact on my life. So, that sort of consumed my life, or I ventured to make it part of my life.}

Tammie's narrative demonstrates not only her very personal connection to her subject matter, but her own self-directed, spirited epistemology.

\section{SOCIAL SUPPORT AND COMMUNITY BUILDING}

Cat injected the importance of making people feel welcome, accepted and safe in her classroom regardless of skill level. Furthermore, Hill and Johnson (2003) communicate that "addressing spirituality in our adult education practice means bringing our whole selves-mind, spirit, and heart to our work and creating a learning space where learners can do the same (p. 23)." Cat's class was by far the largest one I observed; however, it also seemed to be the most vibrant.

All three educators spoke their express commitment to allowing spirituality to show up when they teach and the importance of making room for it in praxis. While style and tone was completely different from each of the classes I observed; Belinda helps her students to understand drawing complicated objects such as Blue Herring, through the use of shapes. Cat welcomes people to enjoy tap at their own pace and speed; while Tammie gently encouraged her students to do more in class, to think deeper and longer about themselves and their interests.

Vogel (2000) calls for adult educators to reckon our own spiritual lives as this can be life-giving as it helps educators find ways to invite students to reckon with their spiritual lives. "Once we open the door to talking about beliefs and the practices of faith, we are called to listen in deep, open ways and to recognize that sharing faith can be done noncoercively so that we are able to understand and honor different life experiences (p. 21)."

An additional aspect of support and community building can be seen as initially developed through the educators own life experience. For example, Tammie's connection to Eastern religion provides the pathway to further explore the importance of spirituality in their lives and professional practice, outside of formal dogmatic worship. Belinda and Cat both shared with me prior professional experiences that were transformative insofar as not feeling connected to a particular place or job because of the people or politics involved. Understanding what doesn't feel comfortable or conducive to learning and growth has helped inform their work in explicitly trying to create inclusive spaces.

Cat shared with me the following about retiring from her job with the Town of Cary because of a bad supervisor: 
At our age we don't need to do anything we don't want to do. I worked for the town as a center supervisor and I have had many, many good supervisors of my own, and then a supervisor came in and we just did not gel. It taught me that I want to bring something positive in-and I had that "aha" moment. Now, I teach.

Cat's account of vocational experience lends itself to the words of Vogel (2000), who states that adults need "time and space to express and heal the inevitable pains and hurt of life." She further goes on to reinforce the importance of these emotions in adult education: "When these factors are present in adult learners, teaching is greatly enhanced. When teachers are in touch with their own spiritual journeys, they engage learners in ways that encourage them to explore all dimensions of a topic (p.20)." In summary, it is important to be in touch with previous life experiences in order to be fully present in the teaching moment and encourage an authentic and meaningful dialogue with students that may be struggling and suffering. Having a clear connection to the past helps us to understand how and why we see the world the way we do and how it informs our practice.

\section{DISCUSSION}

In closing, examining the role of spirituality in adult education has revealed varied life experiences and deeply personal narratives. Understanding the impact spirituality has on teaching practice with the three adult educators interviewed for the study show an individual, inextricable link to worldview and life experience. It does not seem possible to impart spirituality in adult education without an adult educator that recognizes and adheres to spirituality as a clear value, intrinsically supported by guiding principles and theory as seen in the literature. Tolliver and Tisdell (2006) submit the importance of purposely creating a learning environment in adult education that invites multiple dimensions of learning, including affective, relational, imaginal and symbolic dimensions of learning.

The findings of this study indicate an enacted value that influences teaching practice; whether explicitly or implicitly; thus this finding adds to the current narrative, providing another layer of testimony to the conceptual framework on the role of spirituality in adult education. Tolliver and Tisdell (2006) impart that spirituality in practice looks similar to what occurred at the senior center, stating, "It involves authenticity, openness, acceptance and honoring of the various dimensions of how people learn (p. 40)." Two possible areas of delineation and distinction can be seen through the specific population demographics and the nonformal nature of the learning experience.

The narrative provided several significant findings that support the research questions. For instance, the concept of being "present" and "in the here and now" with students, "creating positive learning encounters", providing "personal oneon-one attention," additionally, using "intellectual spirituality" when working with adult learners, all provide insight and ground how educators utilize spirituality in their practice. Further, the concept of capacity building is salient as it appeared in all my participant interviews and observations. One of the instructors shared that the class or subject matter is simply the medium, but the message is the connection. The importance of connectedness is an integral component to using spirituality in adult education. Equally significant, is the notion of strength building and welcoming all skill levels is a significant factor in developing a spiritually grounded teaching practice.

The second research question regarding the educator's personal definition of spirituality had several consistent findings. Two of the three participants referred to "aha" moments, referring to enlightenment, and the tacit importance of positivity and acceptance. Poignantly, the personal life history or lived experience of the adult educator is inextricably linked to their personal self-concept and spiritual identity. While through the aging process and life challenges, as participants often referred back to personal struggles, i.e., divorce, death and career challenges. It is my contention that the essence of our spiritual development is fostered during periods of adversity and it is this lens that provides the personal capability to nurture a spiritually grounded educational experience.

Future research might focus on the examination of lifelong learning policy with spirituality as core value in senior center learning. Opportunities to critically examine mentoring in adult education and the role of spirituality in senior centers may also add to the current narrative. 
In conclusion, the role of spirituality in adult teaching and learning is present when the instructor invites and welcomes the openness of spirituality to the classroom. The development of a spiritual paradigm is informed by a deeply personal life narrative and belief system. Inviting this practice to adult education provides a wonderfully complex and rich learning experience that transcends classroom boundaries. In order to really grasp and understand the impact of spirituality and teaching practice, one must first examine the life experience of the adult educator, as stated by Palmer (2007) "As we teach who we are." Thus, one cannot fundamentally understand the spiritual aspect of teaching without knowing the teacher. As educators, in order to advance the practice of spirituality in adult education, we must ask the right questions, listen to the stories, and examine the deeply held values of those that guide our learning process. It is only through creating a personal connection to the subject matter that the educator can begin to use their life experience as a conduit to welcome the participant's spiritual growth and development. The adult educator weaves a complex web, traversing back and forth from facilitator to spiritual conduit; this is a skill that develops over a lifetime, but has the potential to be harnessed and deployed in more adult educators and in future practice.

\section{References}

Baxter, P., \& Jack, S. (2008). Qualitative case study methodology: Study design and implementation for novice researchers. The Qualitative Report, 13(4), 544-559.

Beringer, A. (2000). In search of the sacred: A conceptual analysis of spirituality. Journal of Experiential Education, 23(3), 157165.

Brookfield, S. D (1995). Becoming a critically reflective teacher. San Francisco: Jossey-Bass.

Brookfield, S. (1998). Critically reflective practice. Journal of Continuing Education in the Health Professions, 18(4), 197205

Brookfield, S. D. (2010). Theoretical frameworks for understanding the field. In Kasworm, C. (Eds). Handbook of Adult and Continuing Education (pp. 71-82) Los Angeles: SAGE.

Colley, H., Hodkinson, P., \& Malcolm, J. (2002). Non-formal learning: mapping the conceptual terrain. Consultation report, Leeds: University of Leeds Lifelong Learning Institute. Also available in the informal education archives: http://www.infed. org/archives/etexts/colley_informal_learning. htm.

Dirkx, J. M. (1997). Nurturing soul in adult learning. New Directions for Adult and Continuing Education, (74), 79-88.

Eaton, J., \& Salari, S. (2005). Environments for lifelong learning in senior centers. Educational Gerontology, 31(6), 461-480.

English, L. M. (2000). Spiritual dimensions of informal learning. New Directions for Adult and Continuing Education, (85), 29-38.

Gray, B. (2004). Informal Learning in an Online Community of Practice. Journal of Distance Education, 19(1), 20-25.

Hill, L. H., \& Johnston, J. D. (2003). Adult education and humanity's relationship with nature reflected in language, metaphor, and spirituality: A call to action. New directions for Adult and Continuing Education, 99, 17-26.

Knowles, M. (1973). The Adult Learner: A Neglected Species. Houston, TX: Gulf.

Martinson, K., \& O'Brien, C. (2010).Conducting Case Studies. In Wholey, J. S., Hatry, H. P., \& Newcomer, K. E. (Ed.), Handbook of Practical Program Evaluation (pp. 163-181). San Francisco, CA: Jossey-Bass.

Merriam, S. B. (1988). Case study research in education: A qualitative approach. San Franscisco Jossey-Bass.

Merriam, S. B. (1998). Qualitative Research and Case Study Applications in Education. Revised and Expanded from Case Study Research in Education.San Francisco, CA: JosseyBass

Merriam, S. B. (2004). The role of cognitive development in Mezirow's transformational learning theory. Adult Education Quarterly, 55(1), 60-68.

Milacci, F. A. (2006). Moving towards faith: An inquiry into spirituality in adult education. Christian Higher Education, 5(3), 211-233.

Mezirow, J. (1991). Transformation theory: Critique and confusion. Adult Education Quarterly, 42(4), 250-252.

Palmer, P. J. (2003). Teaching with heart and soul reflections on spirituality in teacher education. Journal of Teacher Education, 54(5), 376-385.

Palmer, P. (2007). The courage to teach. Exploring the Inner Landscape of a Teacher's Life. San Francisco, CA: JosseyBass.

O'Donnell, V. L., \& Tobbell, J. (2007). The transition of adult students to higher education: Legitimate peripheral participation in a community of practice? Adult Education Quarterly, 57(4), 312-328. 
Orr, J. A. (2000). Learning from native adult education. New Directions for Adult and Continuing Education, 85, 59-66.

Taylor, S.J., \& Bogdan, R. (1998). Introduction to Qualitative Research Methods. New York, John Wiley \& Sons.

Tisdell, E. J. (2000). Spirituality and emancipatory adult education in women adult educators for social change. Adult Education Quarterly, 50(4), 308-335

Tisdell, E. J. (2003). Exploring Spirituality and Culture in Adult and Higher Education. New York, NY: John Wiley \& Sons.

Tisdell, E. J., \& Tolliver, D. E. (2003). Claiming a Sacred Face: The Role of Spirituality and Cultural Identity in Transformative Adult Higher Education. Journal of Transformative Education, 1(4), 368-392.

Vella, J. (2000). A spirited epistemology: Honoring the adult learner as subject. New Directions for Adult and Continuing education, 85, 7-16.

Vogel, L. J. (2000). Reckoning with the spiritual lives of adult educators. New Directions for Adult and Continuing Education, 85, 17-27.

Wickett, R. E. Y. (2000). The learning covenant. New Directions for Adult and Continuing Education, 85, 39-47.

Yin, R. (1996). Case study research-Design and methods. (5th ed.) London: Sage

Yin, R. K. (2011). Qualitative research from start to finish. New York, Guilford Press.

\section{Author Biography}

Laura Demarse holds a doctorate in Higher Education from the University of Memphis and a Masters in Counseling Psychology from Fordham University. She is currently the Director of the Office of Postdoctoral Affairs at NC State University. Prior to serving in this role, Laura has served as Assistant Dean, in the School of Business at NC Central University, Assistant Dean of Postdoctoral Affairs at the University of Utah and Director of Career Development at the College of Charleston. Laura is a Nationally Certified Counselor, Master Career Counselor and advocate for professional and career development for postdocs. 